\title{
ONLINE LEARNING INTERACTION OF MATHEMATICS TEACHER IN JUNIOR HIGH SCHOOL: A SURVEY IN THE COVID-19 PANDEMIC
}

\author{
Ahmad $^{* 1}$, Zulkifley Mohamed ${ }^{2}$, Eka Setyaningsih ${ }^{1}$, Chumaedi Sugihandardji ${ }^{1}$ \\ ${ }^{1}$ Universitas Muhammadiyah Purwokerto, Indonesia \\ ${ }^{2}$ Universiti Pendidikan Sultan Idris, Malaysia
}

\begin{tabular}{l}
\hline \hline Article Info \\
\hline Article history: \\
Received May 26, 2021 \\
Revised Aug 1, 2021 \\
Accepted Aug 6, 2021 \\
\hline
\end{tabular}

\section{Keywords:}

Classroom interaction, COVID-19,

Mathematics teachers, Online learning

\begin{abstract}
This study aims to determine the online learning interactions carried out by junior high school teachers in the classroom during the COVID-19 pandemic. The quantitative using survey was used as a research methodology. 141 Mathematic Teachers was selected as the subject of this research. A questionnaire of classroom interaction practice in an online class was used as a data collection technique. The result found that mathematic teachers' interaction activity in online courses has a different level. The interaction process that mathematic teachers use is in preparing the students to join an online course and leading the discussion with the mean of 4.2 and 4.3. In contrast, the lowest interaction happens in interaction in giving feedback and interaction in closing activity with an average of 2.5. the research also found that $78.70 \%$ of mathematic teachers always provide direction to the students in starting the online class. $40.30 \%$ of them never ask students to correct incorrect assignments during online learning.
\end{abstract}

Copyright $(2021$ IKIP Siliwangi. All rights reserved.

\section{Corresponding Author:}

Ahmad,

Departement of Mathematics Education,

Universitas Muhammadiyah Purwokerto

Jl. KH. Ahmad dahlan, Purwokerto, Central Java 45133, Indonesia

Email: ahmad@ump.ac.id

\section{How to Cite:}

Ahmad, A., Mohamed, Z., Setyaningsih, E., \& Sugihandardji, C. (2021). Online learning interaction of mathematics teacher in junior high school: A survey in the COVID-19 pandemic. Infinity, 10(2), 271-284.

\section{INTRODUCTION}

The use of online learning is currently being used in various fields, including in education, especially in the times of COVID-19 (Bao, 2020). Online learning is growing because technology makes the learning process can be done more efficiently in terms of time, distance, and cost (Abidah et al., 2020). Despite the advantages of online class, it has also a limitation in the term of interaction (Moore et al., 2011). The online learning interactions that occur in the classroom through communication media that utilize internet technology (Alabdulaziz, 2021; Borba et al., 2016; Haleva et al., 2021; Mulenga \& Marbán, 2020; Rosa \& Lerman, 2011; Sullivan et al., 2020). This can lead to a lack of interaction between teachers and students and students with others.

Classroom interaction is actually the most important element in all aspects in running the education (Markee, 2015). Without good interaction there will be no social life, social 
groups nor the social system (Schwarz et al., 2009). This kind of interaction will only occur when these individuals or human groups to cooperate, talk, competition or even holding disputes and so on.

Classroom interaction is a dynamic process that which concerns the relationship between individuals and individuals, between individuals and groups, or between groups and groups. Teaching and learning interactions contain a meaning of the interaction activities of the teaching staff who carry out the task teaching on the one hand, with learning groups (students, students / learning subjects) who are carrying out learning activities on the other side (Mercer \& Howe, 2012). In Government Regulation Number 19 of 2005 concerning Standards National Education mentioned that the learning process in the class is held in an interactive, inspirational, fun, challenging, motivating students to participate actively, and provide sufficient space for initiative, creativity, and independence according to talents, interests, and physical and psychological development of students (Ulum, 2020).

To achieve a good classroom interaction in online class, the role of teachers is very important (Webb, 2009). Teachers in online class can do some pattern of interaction namely, asynchronous pattern and Synchronous pattern (Naranjo et al., 2017; Rex \& Schiller, 2009). The difference in interaction patterns is characterized by the time in accessing learning activities. The asyncronous pattern is usually carried out by the teacher by providing all teaching materials and learning display materials so that students can access them at different times (Bao, 2020). Students also can respond to teaching materials and broadcast materials at different times. While syncronous is a pattern where the process of delivering subject matter is carried out simultaneously (Bennett et al., 2008). Educators present learning materials that are also directly accessible to students simultaneously. So, there is a collaborative process between students and teachers when learning activities happen (Mawad, 2020).

Teachers also should be able to put the interaction in every stage of learning, namely: opening stage, connection stage, action stage and reflection and evaluation stage. In opening stage, the teacher provides instructions about the identity of the subjects and the learning objectives that must be achieved (Hendriana, Prahmana, \& Hidayat, 2018; Irfan et al., 2020; Nasution et al., 2021; van Manen, 2016; Watkins \& Scott, 2012). After this stage is completed, then the teacher provides the second stage, namely Connection, which is to give positive questions about students' initial knowledge of the material to be discussed and connect the previous material with the material to be studied (Payler, 2007). At this stage the teacher also builds psychological relationships with students. The Action stage becomes the stage where students access the resources and teaching materials prepared by the teacher in the form of videos, interactive slides and e-books (van Manen, 2016; Watkins \& Scott, 2012). Teachers need to provide more time for students to understand and read the material as well as provide time for consultation through applications such as zoom aplication, chatting, and so on. This process is a syncronous process between students and teachers. The next activity is reflection and evaluation; teachers can use a quiz or other online assessment (Swan et al., 2006). From the data presented above the key to the interaction in online class is very important to investigate for the betterness of the intruction. Thus, this study aimed at finding out the classroom interaction of mathematic class in online learning.

\section{METHOD}

Descriptive quantitative using survey was used in this research. The subject of this research was 141 Mathematic teachers from Banyumas regency. The number was based on 
Slovin's formula to calculate the sample size necessary to achieve a certain confidence interval when sampling a population This research was done on September 2020.

Questionaire was used in this reaseach to investigatethe interaction process in online class during COVID-19. The questionnaires contain closed questions type to respond by teachers with 20 questions. The organization of the questionnaire was adjusted to the instrument indicators based on the theoretical studies carried out. The indicators of the questionaire include : preparing the students to join online class, guiding students during the activity in online class, leading the discussion, giving feedback, and interaction in closing activity. The questionnaire in this research was made by likert scale, each variable provide 4 alternative answers such as very often (SS), often (S), seldom (J), and never (TP). The respondents fill one of the option from the alternatives that is suitable with them. After filling out the data of the questionaire, the data then calculated and analyze using descriptive stattstics to find out the average score and the percentage of the result.

\section{RESULTS AND DISCUSSION}

\subsection{Results}

Statistic Descriptive Analysis used for analyzing data by describing collective data from each variable studied after the research was carried out so that it is easier to understand. The average of the teachers' interaction process in online class during COVID-19 times (see Table 1).

Table 1. Teachers' classroom interaction in online class

\begin{tabular}{clcc}
\hline No & \multicolumn{1}{c}{ Interaction indicators } & Average & Level of interaction \\
\hline 1 & Preparing the students to join online class & 4.2 & High \\
\hline 2 & $\begin{array}{l}\text { Guiding students during the activity in } \\
\text { online class }\end{array}$ & 3.5 & Medium \\
\hline 3 & Leading the discussion & 4.3 & High \\
\hline 4 & Giving feedback & 2.5 & Low \\
\hline 5 & Interaction in closing activity & 2.7 & Low \\
\hline
\end{tabular}

Table 1 show that teachers' classroom interaction in online class are varied in the level of interaction. Preparing the students to join online class and leading the discussion have the high level of interaction with the mean of 4.2 and 4.3. Guiding students during the activity in online class has a medium level of interaction with the average 3.5. The low interaction was found on giving feedback and interaction in closing activity with 2.5. In detail the classroom interaction in every indicators can be seen in following explanation.

\subsubsection{Preparing the students to join online class}

The result of mathematic teachers' interaction in preparing the students to join online class can be seen on the Table 2 . 
Table 2. Preparing the students to join online class

\begin{tabular}{clcccc}
\hline $\begin{array}{c}\text { Number } \\
\text { of items }\end{array}$ & \multicolumn{1}{c}{ Statements } & Always & Often & Sometimes & Never \\
\hline 1 & $\begin{array}{l}\text { I give a direction to } \\
\text { students in starting online } \\
\text { class }\end{array}$ & $78.70 \%$ & $11.40 \%$ & $9.40 \%$ & $0.50 \%$ \\
\hline 2 & $\begin{array}{l}\text { I make sure all students are } \\
\text { ready to start the online } \\
\text { class }\end{array}$ & $64.80 \%$ & $9.70 \%$ & $3.90 \%$ & $21.60 \%$ \\
\hline 3 & $\begin{array}{l}\text { I contacted students who } \\
\text { were unable to participate } \\
\text { in online class }\end{array}$ & $12.30 \%$ & $50.40 \%$ & $35.60 \%$ & $1.70 \%$ \\
\hline 4 & $\begin{array}{l}\text { I provide solutions to } \\
\text { students who have } \\
\text { difficulty starting online } \\
\text { class }\end{array}$ & $59.00 \%$ & $5.50 \%$ & $32.20 \%$ & $3.00 \%$ \\
\hline & & & & \\
\hline
\end{tabular}

Table 2 describes the classroom interaction conducted by mathematics teacher in Preparing the students to join online class. The result showed that is always given by the tecahers is giving the direction to the students in starting the online class with $78.70 \%$. $50.40 \%$ of tecahers often contacted students who were unable to participate in online class. Moreover, $32.20 \%$ of teachers sometimes provide solutions to students who have difficulty starting online class. Finally, $21.60 \%$ of tecahers never make sure all students are ready to start the online class. This shows that online learning is currently not used by students and teachers, so it is still necessary to adjust the use of media to be better in the online teaching and learning process (Hebebci et al., 2020; Herliandry et al., 2020; Johns \& Mills, 2021; König et al., 2020; Rodríguez-Muñiz et al., 2021).

\subsubsection{Guiding students during the activity in online class}

The result of mathematic teachers' interaction in guiding students during the activity in online class can be seen on the Table 3 .

Table 3. Guiding students during the activity in online class

\begin{tabular}{clcccc}
\hline $\begin{array}{c}\text { Number } \\
\text { of items }\end{array}$ & \multicolumn{1}{c}{ Statements } & Always & Often & Sometimes & Never \\
\hline 1 & $\begin{array}{l}\text { I discuss the learning } \\
\text { objectives students during } \\
\text { online learning }\end{array}$ & $28.70 \%$ & $31.40 \%$ & $29.40 \%$ & $10.50 \%$ \\
\hline 2 & $\begin{array}{l}\text { I communicate learning } \\
\text { materials to students }\end{array}$ & $24.80 \%$ & $39.70 \%$ & $13.90 \%$ & $21.60 \%$ \\
\hline 3 & $\begin{array}{l}\text { I guide every activity in } \\
\text { online class }\end{array}$ & $12.30 \%$ & $50.40 \%$ & $35.60 \%$ & $1.70 \%$ \\
\hline 4 & $\begin{array}{l}\text { I check the activeness of } \\
\text { student in online class }\end{array}$ & $49.00 \%$ & $25.50 \%$ & $12.20 \%$ & $13.00 \%$ \\
\hline
\end{tabular}


Table 3 describes the interaction in guiding students during the activity in online class. The result is varied. The majority of teachers always check the activeness of student in online class with $49 \% .50 .40 \%$ often guide every activity in online class, and $35.60 \%$ of them sometimes do it. Finally, $21.60 \%$ of teahers never communicate learning materials to students. This happens because teachers are not used to interacting in online learning, making it difficult for teachers to guide students individually (Hasan \& Khan, 2020; Hebebci et al., 2020; Johns \& Mills, 2021; König et al., 2020; Mehall, 2020; Mumford \& Dikilitaş, 2020; Rodríguez-Muñiz et al., 2021; van den Berg, 2020).

\subsubsection{Leading the discussion}

The result of mathematic teachers' interaction in leading the discussion can be seen on the Table 4.

Table 4. Leading the discussion

\begin{tabular}{clcccc}
\hline $\begin{array}{c}\text { Number } \\
\text { of items }\end{array}$ & \multicolumn{1}{c}{ Statements } & Always & Often & Sometimes & Never \\
\hline 1 & $\begin{array}{l}\text { I opened a questions and } \\
\text { answer forum with students in } \\
\text { online class }\end{array}$ & $68.70 \%$ & $11.40 \%$ & $19.40 \%$ & $0.50 \%$ \\
\hline 2 & $\begin{array}{l}\text { I asked students to ask their } \\
\text { friend if they had trouble } \\
\text { during online class }\end{array}$ & $53.80 \%$ & $9.70 \%$ & $14.90 \%$ & $21.60 \%$ \\
\hline 3 & $\begin{array}{l}\text { I chat directly with students } \\
\text { who have difficulty during a } \\
\text { learning }\end{array}$ & $52.30 \%$ & $40.40 \%$ & $5.60 \%$ & $1.70 \%$ \\
\hline 4 & $\begin{array}{l}\text { I answer all student questions } \\
\text { in online classes }\end{array}$ & $43.20 \%$ & $5.50 \%$ & $32.20 \%$ & $19.10 \%$ \\
\hline
\end{tabular}

Table 4 discuss about the mathematics teacher classroom interaction in leading the discussion. It can be seen that the majority of mathematic teachers always used classroom interaction in every activity of leading the discussion with the students with $68.70 \% .40 .40 \%$ of them often chat directly with students who have difficulty during a learning. In addition, $32.20 \%$ of teachers sometimes answer all student questions in online class. Finally, $21.60 \%$ of teachers never asked students to ask their friend if they had trouble during online class. This shows that the discussion in class is still dominated by the teacher. Students still do not feel brave to ask questions or respond to questions from teachers or friends. Thus, the ability to ask questions in mathematical learning still needs to be a concern to be developed better (Bosch et al., 2018; Franke et al., 2009; Hendriana, 2017; Hendriana, Hidayat, \& Ristiana, 2018; Hendriana, Rohaeti, \& Hidayat, 2017; Lim et al., 2020; McCarthy et al., 2016; Steyn \& Adendorff, 2020; Way, 2008). 


\subsubsection{Giving feedback}

The result of mathematic teachers' interaction in giving feedback can be seen on the Table 5 .

Table 5. Giving feedback

\begin{tabular}{clcccc}
\hline $\begin{array}{c}\text { Number } \\
\text { of items }\end{array}$ & \multicolumn{1}{c}{ Statements } & Always & Often & Sometimes & Never \\
\hline 1 & $\begin{array}{l}\text { I clearly communicate the } \\
\text { assessment/ assignment } \\
\text { given to students }\end{array}$ & $2.20 \%$ & $16.90 \%$ & $39.40 \%$ & $41.50 \%$ \\
$\quad \begin{array}{l}\text { I provide direct feedback on } \\
\text { the results of online student } \\
\text { assignments }\end{array}$ & $1.80 \%$ & $8.70 \%$ & $63.90 \%$ & $25.60 \%$ \\
\hline 3 & $\begin{array}{l}\text { I write a comment to each } \\
\text { student regarding the } \\
\text { assessment being done }\end{array}$ & $10.30 \%$ & $10.40 \%$ & $55.60 \%$ & $23.70 \%$ \\
\hline 4 & $\begin{array}{l}\text { I ask students to correct } \\
\text { incorrect assignments during } \\
\text { online learning }\end{array}$ & $13 \%$ & $16.50 \%$ & $32.20 \%$ & $40.30 \%$ \\
\hline
\end{tabular}

Table 5 discuss the mathematic teachers' interaction in giving feedback to their students. The result showed that mathematic teachers who always and sometimest write a comment to each student regarding the assessment being done is $10.30 \%$ and $10.40 \%$. In addition, $63.90 \%$ of them provide direct feedback on the results of online student assignments. The last, $40.30 \%$ of mathematic techers never ask students to correct incorrect assignments during online learning. This shows that in online learning, teachers are still adapting and need to improve their technological capabilities in managing online learning (Hebebci et al., 2020; Herliandry et al., 2020; Johns \& Mills, 2021; König et al., 2020; Rodríguez-Muñiz et al., 2021). So, the teacher can conduct a comprehensive assessment of all students (Irfan et al., 2020; Jackson et al., 2013; Lee, 2014; Ryve, 2011).

\subsubsection{Interaction in closing activity}

The result of mathematic teachers' interaction in interaction in closing activity can be seen on the Table 6 .

Table 6. Interaction in closing activity

\begin{tabular}{clcccc}
\hline $\begin{array}{c}\text { Number } \\
\text { of items }\end{array}$ & \multicolumn{1}{c}{ Statements } & Always & Often & Sometimes & Never \\
\hline 1 & $\begin{array}{l}\text { I reflect on learning together } \\
\text { with students }\end{array}$ & $14.20 \%$ & $21.90 \%$ & $39.40 \%$ & $24.50 \%$ \\
\hline 2 & $\begin{array}{l}\text { I give students the opportunity } \\
\text { to work together to make a } \\
\text { summary of the lesson }\end{array}$ & $3.80 \%$ & $9.70 \%$ & $64.90 \%$ & $21.60 \%$ \\
\hline 3 & $\begin{array}{l}\text { I ask students to discuss with } \\
\text { each other in summarizing }\end{array}$ & $12.30 \%$ & $20.40 \%$ & $35.60 \%$ & $31.70 \%$ \\
\hline
\end{tabular}




\begin{tabular}{clcccc}
\hline $\begin{array}{c}\text { Number } \\
\text { of items }\end{array}$ & \multicolumn{1}{c}{ Statements } & Always & Often & Sometimes & Never \\
\hline & $\begin{array}{l}\text { learning outcomes during } \\
\text { online learning }\end{array}$ & & & & \\
\hline 4 & $\begin{array}{l}\text { I motivate students to always } \\
\text { be motivated to follow online } \\
\text { learning }\end{array}$ & $33.00 \%$ & $35,50 \%$ & $31.20 \%$ & $0.30 \%$ \\
\hline
\end{tabular}

Table 6 shows that the interaction in closing activity. $33.00 \%$ and $35.50 \%$ of mathematic teachers motivate students to always and sometimes motivate students to always be motivated to follow online learning. Moreover, $64.90 \%$ of them sometimes give students the opportunity to work together to make a summary of the lesson. Finally, $31.70 \%$ of mathematic teachers never ask students to discuss with each other in summarizing learning outcomes during online learning. This shows that the habits of teachers and students in online learning need to be improved, so that the online learning process will then become more meaningful (Hebebci et al., 2020; Herliandry et al., 2020; Irfan et al., 2020; Johns \& Mills, 2021; König et al., 2020; Rodríguez-Muñiz et al., 2021).

\subsection{Discussion}

The teaching and learning process carried out in the classroom so far is often oneway, where students only listen to what the teacher says (Tularam \& Machisella, 2018). Therefore, the interaction in the class, especially in online class is low. Interaction is also an important point in teaching and learning activities because not only students get the benefit, but also the teachers also get feedback (feedback) whether the material presented can be received by students well (Lockyer \& Dawson, 2011).

There are some components of interaction that should be prepare by teachers, namely: interaction in preparing the students to join online class, guiding students during the activity, leading the discussion, giving feedback and Interaction in closing activity (Payler, 2007). Among those factors, this study revealed that interaction in preparing the students to join online class and leading the discussion was highly used by Mathematic teachers, while interaction in guiding students during the activity is medium. The lowest interaction happened in interaction in giving feedback and closing activity.

Classroom online interaction skills to open lessons are activities carried out by teachers to mentally prepare and generate student attention (Mawad, 2020). This is so that students focus on the things to be learned. Activities to open lessons must not only be carried out by the teacher at the beginning of class hours but also at the beginning of each part of the activity from the core of the lesson given during that lesson (Smith \& Higgins, 2006). To prepare students mentally for the lesson that will be studied, the teacher can make provide the students references and making connections between the subject matter that has been mastered by students with the new material to be studied. Students who are mentally ready to learn are those who already know the objectives of the lesson, and the steps for learning activities to be studied. Therefore, teachers should be warm and enthusiastic in building a good interaction with the students in the beginning of the lesson (Fein \& Logan, 2003; Metros, 2008).

Guiding discussion activities in learning is one of the teaching skills that must be mastered by the teacher, because through discussion students are encouraged to learn actively, learn to express opinions, interact, respect each other, and practice being positive (Cohen, 1994; Dallimore et al., 2004; Hendriana, Prahmana, \& Hidayat, 2018; Irfan et al., 
2020; Nasution et al., 2021). Through the discussion of the teacher's role, the impression that it is too dominating the conversation will automatically disappear. With discussion, students and teachers are both active, even though discussion it can facilitate an active learning process (Cobb et al., 2001; Jesionkowska, Wild, \& Deval, 2020; Koh \& Kan, 2021; Tan et al., 2020; Wang, 2020).

Giving feedback must be possessed by teachers (Burnett \& Mandel, 2010; Kulik \& Kulik, 1988). Competent teachers can do an effective interaction in giving feedback for their students in order to create an effective learning environment and achieve a good student learning outcomes (Ellis, 2009; Montgomery \& Baker, 2007). Student participation in learning should be given feedback by the teacher so that students are motivated to repeat these activities with better quality. Thus, a teacher must be able to maintain student motivation in order to achieve optimal results when carrying out a learning process.

The activity of closing lessons is an activity carried out by the teacher to end the core activities of the lesson (Payler, 2007). Efforts to close the lesson are intended to provide a comprehensive picture of what students have learned, to find out the level of student achievement and the level of success of the teacher in the teaching and learning process. Efforts that can be made by the teacher include summarizing or asking students to summarize and evaluate the subject matter that has just been given (Downer et al., 2010). Like opening lessons, closing lessons must be carried out by the teacher not only at the end of class hours but also at the end of each part of the activity from the core of the lessons given during that lesson. Like opening lessons, closing lessons also does not include sequences of routine activities such as giving assignments at home, but activities that have direct activities with the delivery of lesson material.

\section{CONCLUSION}

The conclusion in this study shows that the interactive activities of mathematics teachers in online classes have different levels. The interaction process used by mathematics teachers is in preparing students to take online courses in leading discussions. In contrast, low interaction occurs in interactions in providing feedback and interactions in closing activities. This happens because in Indonesia, during the current covid-19 pandemic, all sectors do their work online, so the education sector is also affected by online learning. The impact is that teachers who are not familiar with online learning conditions are forced to keep up with speedy technological developments in the teaching and learning process.

\section{ACKNOWLEDGEMENTS}

The authors would like to express my special thanks to Universitas Muhammadiyah Purwokerto for supporting the facilities and financial to accomplish this paper.

\section{REFERENCES}

Abidah, A., Hidaayatullaah, H. N., Simamora, R. M., Fehabutar, D., \& Mutakinati, L. (2020). The impact of COVID-19 to Indonesian education and its relation to the philosophy of "merdeka belajar". Studies in Philosophy of Science and Education, 1(1), 38-49. https://doi.org/10.46627/sipose.v1i1.9 
Alabdulaziz, M. S. (2021). COVID-19 and the use of digital technology in mathematics education. Education and Information Technologies, 1-25. https://doi.org/10.1007/s10639-021-10602-3

Bao, W. (2020). COVID -19 and online teaching in higher education: A case study of Peking University. Human Behavior and Emerging Technologies, 2(2), 113-115. https://doi.org/10.1002/hbe2.191

Bennett, S., Maton, K., \& Kervin, L. (2008). The 'digital natives' debate: A critical review of the evidence. British Journal of Educational Technology, 39(5), 775-786. https://doi.org/10.1111/j.1467-8535.2007.00793.x

Borba, M. C., Askar, P., Engelbrecht, J., Gadanidis, G., Llinares, S., \& Aguilar, M. S. (2016). Blended learning, e-learning and mobile learning in mathematics education. ZDM, 48(5), 589-610. https://doi.org/10.1007/s11858-016-0798-4

Bosch, M., Gascón, J., \& Nicolás, P. (2018). Questioning mathematical knowledge in different didactic paradigms: the case of Group Theory. International Journal of Research in Undergraduate Mathematics Education, 4(1), 23-37. https://doi.org/10.1007/s40753-018-0072-y

Burnett, P. C., \& Mandel, V. (2010). Praise and feedback in the primary classroom: Teachers' and students' perspectives. Australian Journal of Educational \& Developmental Psychology, 10, 145-154.

Cobb, P., Stephan, M., McClain, K., \& Gravemeijer, K. (2001). Participating in classroom mathematical practices. The journal of the Learning Sciences, 10(1-2), 113-163. https://doi.org/10.1207/S15327809JLS10-1-2_6

Cohen, E. G. (1994). Restructuring the classroom: Conditions for productive small groups. Review of Educational Research, 64(1), 1-35. https://doi.org/10.3102/00346543064001001

Dallimore, E. J., Hertenstein, J. H., \& Platt, M. B. (2004). Classroom participation and discussion effectiveness: Student-generated strategies. Communication Education, 53(1), 103-115. https://doi.org/10.1080/0363452032000135805

Downer, J., Sabol, T. J., \& Hamre, B. (2010). Teacher-child interactions in the classroom: Toward a theory of within-and cross-domain links to children's developmental outcomes. Early Education and Development, 21(5), 699-723. https://doi.org/10.1080/10409289.2010.497453

Ellis, R. (2009). Corrective feedback and teacher development. L2 Journal, 1(1), 3-18. https://doi.org/10.5070/12.v1i1.9054

Fein, A. D., \& Logan, M. C. (2003). Preparing instructors for online instruction. New Directions for Adult and Continuing Education,2003(100), 45-55. https://doi.org/10.1002/ace.118

Franke, M. L., Webb, N. M., Chan, A. G., Ing, M., Freund, D., \& Battey, D. (2009). Teacher questioning to elicit students' mathematical thinking in elementary school classrooms. Journal of Teacher Education, 60(4), 380-392. https://doi.org/10.1177/0022487109339906

Haleva, L., Hershkovitz, A., \& Tabach, M. (2021). Students' activity in an online learning environment for Mathematics: The role of thinking levels. Journal of Educational Computing Research, 59(4), 686-712. https://doi.org/10.1177/0735633120972057 
Hasan, N., \& Khan, N. H. (2020). Online teaching-learning during COVID-19 pandemic: Students' perspective. The Online Journal of Distance Education and $e$ Learning, 8(4), 202-213.

Hebebci, M. T., Bertiz, Y., \& Alan, S. (2020). Investigation of views of students and teachers on distance education practices during the coronavirus (COVID-19) pandemic. International Journal of Technology in Education and Science, 4(4), $267-$ 282. https://doi.org/10.46328/ijtes.v4i4.113

Hendriana, H. (2017). Senior high school teachers' mathematical questioning ability and metaphorical thinking learning. Infinity Journal, 6(1), 51-58. https://doi.org/10.22460/infinity.v6i1.p51-58

Hendriana, H., Hidayat, W., \& Ristiana, M. G. (2018). Student teachers' mathematical questioning and courage in metaphorical thinking learning. Journal of Physics: Conference Series, 948(1), 012019. https://doi.org/10.1088/17426596/948/1/012019

Hendriana, H., Prahmana, R. C. I., \& Hidayat, W. (2018). Students' performance skills in creative mathematical reasoning. Infinity Journal, 7(2), 83-96. https://doi.org/10.22460/infinity.v7i2.p83-96

Hendriana, H., Rohaeti, E. E., \& Hidayat, W. (2017). Metaphorical thinking learning and junior high school teachers' mathematical questioning ability. Journal on Mathematics Education, 8(1), 55-64. https://doi.org/10.22342/jme.8.1.3614.55-64

Herliandry, L. D., Nurhasanah, N., Suban, M. E., \& Kuswanto, H. (2020). Pembelajaran pada masa pandemi covid-19. JTP-Jurnal Teknologi Pendidikan, 22(1), 65-70. https://doi.org/10.21009/jtp.v22i1.15286

Irfan, M., Kusumaningrum, B., Yulia, Y., \& Widodo, S. A. (2020). Challenges during the pandemic: use of e-learning in mathematics learning in higher education. Infinity Journal, 9(2), 147-158. https://doi.org/10.22460/infinity.v9i2.p147-158

Jackson, A. T., Brummel, B. J., Pollet, C. L., \& Greer, D. D. (2013). An evaluation of interactive tabletops in elementary mathematics education. Educational Technology Research and Development, 61(2), 311-332. https://doi.org/10.1007/s11423-0139287-4

Jesionkowska, J., Wild, F., \& Deval, Y. (2020). Active learning augmented reality for STEAM education: A case study. Education Sciences, 10(8), 198. https://doi.org/10.3390/educsci10080198

Johns, C., \& Mills, M. (2021). Online mathematics tutoring during the COVID-19 pandemic: Recommendations for best practices. Primus, 31(1), 99-117. https://doi.org/10.1080/10511970.2020.1818336

Koh, J. H. L., \& Kan, R. Y. P. (2021). Students' use of learning management systems and desired e-learning experiences: are they ready for next generation digital learning environments?. Higher Education Research \& Development, 40(5), 995-1010. https://doi.org/10.1080/07294360.2020.1799949

König, J., Jäger-Biela, D. J., \& Glutsch, N. (2020). Adapting to online teaching during COVID-19 school closure: teacher education and teacher competence effects among early career teachers in Germany. European Journal of Teacher Education, 43(4), 608-622. https://doi.org/10.1080/02619768.2020.1809650 
Kulik, J. A., \& Kulik, C. L. C. (1988). Timing of feedback and verbal learning. Review of educational research, 58(1), 79-97. https://doi.org/10.3102/00346543058001079

Lee, J. (2014). An exploratory study of effective online learning: Assessing satisfaction levels of graduate students of mathematics education associated with human and design factors of an online course. International Review of Research in Open and Distributed Learning, 15(1), 111-132. https://doi.org/10.19173/irrodl.v15i1.1638

Lim, W., Lee, J. E., Tyson, K., Kim, H. J., \& Kim, J. (2020). An integral part of facilitating mathematical discussions: Follow-up questioning. International Journal of Science and Mathematics Education, 18(2), 377-398. https://doi.org/10.1007/s10763-01909966-3

Lockyer, L., \& Dawson, S. (2011). Learning designs and learning analytics. In Proceedings of the 1st international conference on learning analytics and knowledge (pp. 153156). https://doi.org/10.1145/2090116.2090140

Markee, N. (2015). The handbook of classroom discourse and interaction. New Jersey: John Wiley \& Sons. https://doi.org/10.1002/9781118531242

Mawad, G. (2020). Impact of electronic interaction patterns in a collaborative learning and instructional anchors-based environment on developing instructional design skills and achievement motivation. International Journal of Education and Practice, 8(1), 86-105. https://doi.org/10.18488/journal.61.2020.81.86.105

McCarthy, P., Sithole, A., McCarthy, P., Cho, J. P., \& Gyan, E. (2016). Teacher questioning strategies in mathematical classroom discourse: A case study of two grade eight teachers in Tennessee, USA. Journal of Education and Practice, 7(21), 80-89.

Mehall, S. (2020). Purposeful Interpersonal Interaction in Online Learning: What Is It and How Is It Measured?. Online Learning, 24(1), 182-204. https://doi.org/10.24059/olj.v24i1.2002

Mercer, N., \& Howe, C. (2012). Explaining the dialogic processes of teaching and learning: The value and potential of sociocultural theory. Learning, culture and social interaction, 1(1), 12-21. https://doi.org/10.1016/j.lcsi.2012.03.001

Metros, S. E. (2008). The educator's role in preparing visually literate learners. Theory into practice, 47(2), 102-109. https://doi.org/10.1080/00405840801992264

Montgomery, J. L., \& Baker, W. (2007). Teacher-written feedback: Student perceptions, teacher self-assessment, and actual teacher performance. Journal of Second Language Writing, 16(2), 82-99. https://doi.org/10.1016/j.jslw.2007.04.002

Moore, J. L., Dickson-Deane, C., \& Galyen, K. (2011). e-Learning, online learning, and distance learning environments: Are they the same?. The Internet and higher education, 14(2), 129-135. https://doi.org/10.1016/j.iheduc.2010.10.001

Mulenga, E. M., \& Marbán, J. M. (2020). Prospective teachers' online learning mathematics activities in the age of COVID-19: A cluster analysis approach. EURASIA Journal of Mathematics, Science and Technology Education, 16(9), em1872. https://doi.org/10.29333/ejmste/8345

Mumford, S., \& Dikilitaş, K. (2020). Pre-service language teachers reflection development through online interaction in a hybrid learning course. Computers \& Education, 144, 103706. https://doi.org/10.1016/j.compedu.2019.103706 
Naranjo, C. A., Ortiz, J. S., Álvarez, V. M., Sánchez, J. S., Tamayo, V. M., Acosta, F. A., Proaño, L. E., \& Andaluz, V. H. (2017). Teaching process for children with autism in virtual reality environments. In Proceedings of the 2017 9th International Conference on Education Technology and Computers (pp. 41-45). https://doi.org/10.1145/3175536.3175582

Nasution, M. D., Ahmad, A., \& Mohamed, Z. (2021). Pre service teachers'perception on the implementation of project based learning in mathematic class. Infinity Journal, 10(1), 109-120. https://doi.org/10.22460/infinity.v10i1.p109-120

Payler, J. (2007). Opening and closing interactive spaces: shaping four-year-old children's participation in two English settings. Early Years, 27(3), 237-254. https://doi.org/10.1080/09575140701594392

Rex, L. A., \& Schiller, L. (2009). Using discourse analysis to improve classroom interaction. New York: Routledge. https://doi.org/10.4324/9780203876985

Rodríguez-Muñiz, L. J., Burón, D., Aguilar-González, Á., \& Muñiz-Rodríguez, L. (2021). Secondary mathematics teachers' perception of their readiness for emergency remote teaching during the COVID-19 pandemic: A case study. Education Sciences, 11(5), 228. https://doi.org/10.3390/educsci11050228

Rosa, M., \& Lerman, S. (2011). Researching online mathematics education: Opening a space for virtual learner identities. Educational Studies in Mathematics, 78(1), 69-90. https://doi.org/10.1007/s10649-011-9310-9

Ryve, A. (2011). Discourse research in mathematics education: A critical evaluation of 108 journal articles. Journal for research in mathematics education, 42(2), 167-198. https://doi.org/10.5951/jresematheduc.42.2.0167

Schwarz, B., Dreyfus, T., \& Hershkowitz, R. (2009). Transformation of knowledge through classroom interaction. London: Routledge. https://doi.org/10.4324/9780203879276

Smith, H., \& Higgins, S. (2006). Opening classroom interaction: The importance of feedback. Cambridge journal of education, 36(4), 485-502. https://doi.org/10.1080/03057640601048357

Steyn, G., \& Adendorff, S. A. (2020). Questioning techniques used by foundation phase education students teaching mathematical problem-solving. South African Journal of Childhood Education, 10(1), 1-9. https://doi.org/10.4102/sajce.v10i1.564

Sullivan, P., Bobis, J., Downton, A., Feng, M., Hughes, S., Livy, S., McCormick, M., \& Russo, J. (2020). Threats and opportunities in remote learning of mathematics: implication for the return to the classroom. Mathematics Education Research Journal, 32(3), 551-559. https://doi.org/10.1007/s13394-020-00339-6

Swan, K., Shen, J., \& Hiltz, S. R. (2006). Assessment and collaboration in online learning. Journal of asynchronous learning networks, 10(1), 45-62. https://doi.org/10.24059/olj.v10i1.1770

Tan, H. R., Chng, W. H., Chonardo, C., Ng, M. T. T., \& Fung, F. M. (2020). How chemists achieve active learning online during the COVID-19 pandemic: using the Community of Inquiry (CoI) framework to support remote teaching. Journal of Chemical Education, 97(9), 2512-2518. https://doi.org/10.1021/acs.jchemed.0c00541 
Tularam, G. A., \& Machisella, P. (2018). Traditional vs non-traditional teaching and learning strategies: The case of e-learning!. International Journal for Mathematics Teaching and Learning, 19(1), 129-158.

Ulum, M. (2020). Kebijakan standar nasional pendidikan. Syaikhuna, 11(1), 105-116. https://doi.org/10.36835/syaikhuna.v11i1.3845

van den Berg, G. (2020). Context matters: Student experiences of interaction in open distance learning. Turkish Online Journal of Distance Education, 21(4), 223-236. https://doi.org/10.17718/tojde.803411

van Manen, M. (2016). The tact of teaching: The meaning of pedagogical thoughtfulness. New York: Routledge. https://doi.org/10.4324/9781315417134

Wang, Y. H. (2020). Design-based research on integrating learning technology tools into higher education classes to achieve active learning. Computers \& Education, 156, 103935. https://doi.org/10.1016/j.compedu.2020.103935

Watkins, C., \& Scott, L. (2012). From the stage to the studio: How fine musicians become great teachers. Oxford: Oxford University Press. https://doi.org/10.1093/acprof:osobl/9780199740529.001.0001

Way, J. (2008). Using questioning to stimulate mathematical thinking. Australian Primary Mathematics Classroom, 13(3), 22-27.

Webb, N. M. (2009). The teacher's role in promoting collaborative dialogue in the classroom. British Journal of Educational Psychology,79(1), 1-28. https://doi.org/10.1348/000709908X380772 
